\title{
THE IRAN-IRAQ WAR AND THE ROLE OF AYATOLLAH KHOMEINI
}

\author{
Mehdi Soltanzadeh \\ Mohammad Redzuan Othman
}

\begin{abstract}
A year after the Iranian Revolution, the Iran-Iraq War started on September 1980. At first, most countries treated this war as nothing more than border skirmishes between two neighbouring countries but surprisingly it became a major challenge and lasted for eight years. The war finally ended when both Iraq and Iran accepted UN Resolution 598 in August 1988. This ended the eight-year of Persian Gulf War, the longest and bloodiest conflict between two Third World states after the Second World War. On the afternoon of September 23, 1980, following a series of air strikes on Iranian airfields, the Iraqi army crossed the border into neighboring Iran, igniting a war that lasted for eight years. The main thrust of the invasion aimed at capturing Iraqi-claimed land on Iran's side of the Shatt al-Arab waterway and parts of Iran's oil-rich southwest province of Khuzestan. Iraq's superior military technology and coordination proved disastrous to Iranian defences, which were already in the midst of the Ayatollah Khomeiniled purges that had decimated the regular military's officer corps and destroyed its institutional cohesion in the aftermath of the revolution. In the last years of the war, there were indicators that Iran's soldiers were unwilling and unable to continue the fight because the war aims were not achieved and had lost a string of military battles in some warfront zones. Therefore, Ayatollah Hashemi Rafsanjani they took a risk in persuading the Ayatollah Khomeini to accept the ceasefire. This article examines the role of Ayatollah Khomeini, during the Iran-Iraq War.
\end{abstract}

\section{Introduction}

In the afternoon of September 23, 1980 following a series of air strikes on Iranian airfields, the Iraqi army crossed the border into neighboring 
Iran, igniting a war that was to last nearly eight years. The main reason of the invasion of Iraq was to capture its claimed land on Iran's side of the Shatt al-Arab waterway, which is oil-rich southwest province of Khuzestan. Iraq's good army organization and superior military technology and coordination proved disastrous to Iranian defenses which were already in the midst of the Ayatollah Khomeini-led purges that had decimated the regular military's officer corps and destroyed its institutional cohesion due to aftermath of the revolution. After eight long years of fighting, the war finally ended when both Iraq and Iran accepted UN Resolution 598 in August 1988.

On 22 September 1980, Iraqi forces began a full-scale invasion of Iran. The main thrust of the invasion aimed at capturing Iraqi-claimed land on Iran's side of the Shatt al-Arab waterway and parts of Iran's oil-rich southwest province of Khuzestan. Iraq's superior military technology and coordination proved disastrous to Iranian defenses, which were already in the midst of the Ayatollah khomeinist-led purges that had decimated the regular military's officer corps and destroyed its institutional cohesion. Despite stalwart Iranian resistance, the Iraqi military was able to capture key positions inside Iranian territory, including the strategically important city of Khorramshahr. ${ }^{1}$

During the Iran Iraq war, Ayatollah Khomeini's speech motivated Iranians to seek death on the battlefield. In 1981, amid a fire fight with Iraqi troops, a 13-year old Iranian named Hussein Fahmideh gathered explosives, attached them to himself, charged an Iraqi tank and detonated the explosives-disabling the tank while killing himself. Like that of Hussein's act of self-sacrifice found widespread praise among Iranian. Soon after, the Iranian government plastered his picture on billboards across Tehran and other cities in Iran. Ayatollah Khomeini's doctrine of guardianship of the jurist "velayat-e faqih", which implies Ayatollah Khomeini was their Supreme Leader". Ayatollah Khomeini's declaration that if the enemy assaults the lands of the Muslims and it's frontiers, it is mandatory for all Muslim and its frontiers, it is mandatory for all Muslims to defend it by all means possible by offering life or property, ${ }^{2}$ he believed that all Muslim state should be all military and have military training. ${ }^{3}$ This Article examines the Ayatollah Khomeini's attitude toward the Iran Iraq war, which is new contribution in this field.

\section{The Roots of the Iran-Iraq War}

The Iran-Iraq border had witnessed multiple border skirmishes in the months leading up to the war. Additionally, insurgent groups conducted guerilla operations within Iran and Iraq with the full support and 
approval of Baghdad and Tehran. ${ }^{4}$ This war is known to be a bloody and an expensive conflict. Towards the end of the war, both Iran and Iraq were feeling the effects of this prolonged war. When the war eventually ended in August 1988, both countries had suffered the following. On the number of casualties, it was estimated that the total war dead was 262,000 Iranians and 105,000 Iraqis. ${ }^{5}$ With another 700,000 injured, this summed up to a total of over one million casualties for the two countries. The Iran-Iraq war has aptly been described as the Third World's first Great War. ${ }^{6}$

At least 157 Iranian towns with populations of more than 5,000 were damaged or wholly destroyed during the war, and some 1,800 border villages were virtually wiped off the map. ${ }^{7}$ Iran and Iraq had suffered enormously in terms of casualties and monetarily during their eight years of war. This war was known to be a most bloody and expensive war. Both countries had a total of over one million casualties and monetary wise the eight-year war had cost both Iraq and Iran in excess of US $\$ 700$ billion each. It was definitely a very high price to pay in trying to achieve one's war aim. ${ }^{8}$

Conventional assessments of the costs of the war tend to focus upon lost oil revenues, declining GNPs, material destruction and even body counts. ${ }^{9}$ Both countries suffered millions of casualties and billions of dollars in damage. The collateral damage to the economies of other nations was also immense. The war was one of the most strategically important conflicts of modern times because it involved two major oil producers and the region where more than half the world's reserves are located. The war between Iran two countries lasted from September 1980 to August 1988. According to UN resolution, Iraq was eventually criticized for breaching international security and peace and was also accused of aggression against Iran. ${ }^{10}$

Neither Iran nor Iraq achieved their war aims during the eightyear war. Iraq's war aim was simply to destabilize and overthrow the Iranian regime through the invasion. ${ }^{11}$ While Iran's war aims were to destroy the Iraqi war machine and the removal of the Ba'th regime in Baghdad and paving the way for Shiite there to rule the country with the hope that this war would become a prime instrument for exporting the Islamic revolution. ${ }^{12}$ Destroying the Iraqi war machine, removing of the Ba'th regime and exporting the revolution were the main priority for Iran during the war. ${ }^{13}$ Anthony Cordesman, in his comprehensive article about Iran-Iraq war in Armed Forces Journal deduced that:

There were several reasons or objectives behind Iraq's decision to move when it did. First, the Iraqis attacked to secure the secular Ba'ath regime 
in Iraq from the Ayatollah's declared intent to overthrow it and to prevent the Iranians from resurrecting the Kurdish Insurgency. ${ }^{14}$

An excuse of territorial disputes between the two states, especially those arising over the Shatt al-Arab waterway said to be the main cause of the war. The basic of this argument draws attention to Iraq's dislike of the 1975 Algiers Agreement which established the boundary of the Shatt al-Arab according to the thalweg (midchannel) principle rather than the eastern shoreline "Even if Iraq and Iran were homogeneous, even if Iraq had no Shi'i problem, the Shatt al-Arab issue would have sufficed to cause war to break out in $1980^{\prime \prime} .{ }^{15}$

After an escalation in border skirmishes between the two countries through the summer of 1980, Iraq launched a full-scale invasion of Khuzistan on September 22, 1980. All indications suggest that Hussein thought the war would be very short. Within a month the Iraqis had seized Khorramshahr and by the end of 1980 they had penetrated up 20 miles of the entire Iranian front. ${ }^{16}$ Within six months of the start of the war, however, Iranian counter-offensives were beginning to take their toll upon the Iraqi army. Two years after the initial invasion the war had for the most part shifted onto Iraqi soil. As the war passed through its third and fourth years it displayedall the features of a deadlocked, attrited and drawn out affair. ${ }^{17}$

Within a month the Iraqis had seized Khorramshahr and by the end of 1980 they had penetrated up 20 miles of the entire Iranian front. ${ }^{18}$ Within six months of the start of the war, however, Iranian counteroffensives were beginning to take their toll upon the Iraqi army. Two years after the initial invasion the war had for the most part shifted into Iraqi soil. As the war passed through its third and fourth years it displayed all the features of a deadlocked, attrited and drawn out affair. ${ }^{19}$ By the autumn of 1981, the ground war had started to turn against Iraq. Iranian offensives pushed the Iraqi army out of many of the areas conquered in the 1980 invasion, prompting Saddam Hussein to announce on April 22, 1982, that he would withdraw his forces from Iranian territory if Tehran would agree to a ceasefire.

Saddam repeatedly asked for ceasefire in June 1982, following the successful Iranian recapture of Khuzestan. All calls for a ceasefire where dismissed by Tehran. By July, the Iranian army had commenced offensive operations aimed at Basra. Iran would remain on the offensive throughout 1983, embarking on many operations, largely unsuccessful, aimed at seizing Iraqi territory. ${ }^{20}$ While Iraq was recovering from the losses received near Shush and Dezful in March, the Iranians launched their most serious offensive up to that time. 
On April 30, 1981 „Operation Jerusalem” or in Persian [amaliate beitolmoghadas] commenced along three axes in the Khuzistan Province. The first axis was in the vicinity of Susangerd which the Iranians had failed to recover in January 1981. The second axis was directed toward the railline and roads which ran from Khorramshahr to Ahvaz and the Iraqi garrison at Hoveyzeh. The third axis was designed to recover Khorramshahr, itself. The Iranian attack was a well-coordinated effort making effective use of the various combat arms. ${ }^{21}$

Infantry night attacks were followed by armor thrusts and fighter aircraft and helicopter support. Initial success was good but stiff resistance was met in the northern area and in front of Khorramshahr, where the Iraqis adopted a more flexible defense. Advice from French and Jordanian advisors apparently assisted the Iraqi regulars in performing better but the Iraqi volunteer units did not fare as well. ${ }^{22}$ The conflicting and erratic nature of Iran's foreign policy in the immediate aftermath of the revolution reflected the intense internal power struggle. ${ }^{23}$ The Iranian plateau is considered the core of Persian civilization. To the west lies Iraq, encompassing the Tigris-Euphrates river basin. The basin has been governed predominantly by both Arab and Turkish rulers. ${ }^{24}$ The two countries conflicts in the region date back to the third century when Sassanid rulers attempted to reestablish a centralized government. ${ }^{25}$

A cultural divide has separated Arabs and Persians since the seventh century when Arab armies conquered Persians east of the Zagros Mountains in western Iran. ${ }^{26}$ The first account draws attention to the deeply rooted cultural enmity between Iran and Iraq and is premised upon a sense of incompatible and immanently hostile societies characterized in racial (Aryan and Semite), sectarian (Shia and Sunni), ethnic (Arab and Persian) or religious (secular and fundamentalist) terms. $^{27}$

A final explanation focuses upon territorial disputes between the two states, especially those arising over the Shatt al-Arab waterway. The basic cut of this argument draws attention to Iraq's dislike of the 1975 Algiers Agreement which established the boundary of the Shatt al-Arab according to the midchannel principle rather than the eastern shoreline:

"Even if Iraq and Iran were homogeneous, even if Iraq had no Shi'i problem, the Shatt al-Arab issue would have sufficed to cause war to break out in $1980^{\prime \prime} .^{28}$

In the broadest possible terms we begin to detect the origins of the IranIraq war by understanding the interaction between 'forces from the international environment and specific local processes and structures 
with their own specific logic' throughout the Twentieth Century. Before 1847, the Shatt-al-Arab was an inland river under the sovereignty of the Ottoman Empire. In 1847, the weakening Ottoman Empire, under the Treaty of Ezerum, formally ceded to the Persian Empire the city of Khorramshahr, the island of Abadan and the anchorage and land on the eastern shore of the Shatt. ${ }^{29}$

The freedom of navigation throughout the Shatt al-Arab was guaranteed to Persian vessels. The resultant agreement, the Algiers Accord of March 6, 1975 benefitted both parties. Iran received Iraq's acceptance that the common boundary was at the middle of the river and that Iraq would no longer support Iranian dissidents and Arab and Baluch secessionists. ${ }^{30}$ Iraq received Iranian agreement to withdraw support of the Iraqi Kurds and agreement by Iran to uphold the status quo of the frontier lands. Iran has historically been the bastion of the Shiites while Iraq has been predominantly oriented to the Sunni branch. ${ }^{31}$ Sunni Moslems believe that the line from Mohammed passed to his daughter Fatima, wife of Ali. The Sunnis discount the Imams, choosing instead to honor a caliph, or successor, their ruler. ${ }^{32}$

Before Islamic revolution in 1979, Iran was an allied but after the revolution became a hostile. For the United States, apart from its main reason being its hostility towards the Islamic Revolution in Iran; supporting Iraq in the war meant that the United States and its Persian Gulf Arab allies had also succeeded in breaching the special relationship between Baghdad and Moscow which had a good relationship..$^{33}$

Excluding Iran and Iraq, Sunni Muslims are in the majority in the Persian Gulf states. The Shiites predominate in Iran, Iraq and Bahrain. ${ }^{34}$ Cultural enmity between Iran and Iraq and is premised upon a sense of incompatible and immanently hostile societies characterized in racial (Aryan Iran and Semite Iraq), sectarian (Shi'i Iran and Sunni Iraq), ethnic (Persian Iran and Arab) or religious (fundamentalist Iran and secular Iraq) terms ${ }^{35}$ Large communities of Persians or their descendants live in Iraq. Between forty and seventy thousand of these Persians were expelled in 1980 by Saddam Hussein. There are three strategic areas in each of the two countries. In Iran, these are Tehran, the oil-rich coastal province of Khuzistan, and the Bandar Abbas area which guards the Straits of Hormuz. ${ }^{36}$

In Iraq the areas of major importance are Baghdad a strategic, political and economic target; the rich oil field of Kiruk, in the north; and the Basra area on the Shatt-al-Arab. ${ }^{37}$ Saddam Hussein's confidence at the outset of the war led him to attach impossible conditions to the first United Nations ceasefire resolution of September 28, 1980. With the turning tides of the war in the next two years, however, Hussein 
became more and more inclined to end it. By the end of 1982 Iraq was clearly prepared to search for a compromise solution to end the war. ${ }^{38}$

The Arab/Persian dimension to the war was trumpeted loudly by the regime, as clearly evident in the name given by Iraq to the war-Quadisiyyat Saddam - which harkens back to the Arab/Persian struggles of the seventh century. In short, the Ba'th regime skilfully held the war out in the cause of the Arab nation. ${ }^{39}$ By the late 1980s, almost a decade after the war had erupted, a few crucial points cannot be overlooked. In Iran, the process of revolutionary consolidation was essentially completed. By 1988, the regime faced 'no internal threat to its power' ${ }^{40}$

The eight-year war with Iraq also weighs heavily on Iran's strategic culture. The military, political, and psychological damage suffered manifests itself in several post-war programs and almost all rhetoric. After impressively winning early battles and repelling Iraq, the Iranians foolishly pushed-on in an effort to invade Iraq and topple Saddam Hussein in what Shahram Chubin suggests was the first step in exporting revolution outside their borders. ${ }^{41}$

The Iran-Iraq war divided the region between Shia Iranians and the Arabs as Iraq claimed to be defending Arab integrity against the Persian threat. This fear was one of the main reasons behind the creation of the Gulf Cooperation Council in $1981 .{ }^{42}$ During the Iran-Iraq War (1980-88), both belligerents targeted each others' oil industry in the hope that economic warfare might bring their adversary to its knees. Oil facilities, tankers, and tanker terminals were hit and though these attacks succeeded in reducing overall oil exports of both sides these attacks were not pressed home in a sustained fashion, and therefore did not have a decisive impact on the outcome of the war. ${ }^{43}$

There were numerous uses of chemical weapons by Iraq against Iranians; apparently, the first Iraqi attacks were conducted in 1982 and used non-lethal "tear gas," but by mid-1983 Iraq was using lethal chemical agents against Iranian troops. ${ }^{44}$ By taking the war to Iran, Iraq terrorized the civilian population, which began to clamor for shelters and to desert the cities in large numbers. Iraq thus imposed a political cost on Iran's leadership for continuing the conflict. The Iranian government's conduct of the war became politically damaging, especially as it was unable to offer the population any defense or to riposte in kind. ${ }^{45}$

This practice wastes ammunition, and is not effective against trained conventional forces. It is more effective, however, against light infantry and insurgents. Iraqi artillery reportedly killed over 200,000 Iranians in the Iran-Iraq War. ${ }^{46}$ After the disastrous Iranian attack on Faw in 1986, Iraq spent hundreds of millions of dollars purchasing ammunition on an emergency basis. Egyptian defense officials said Iraq 
was firing one million shells per day. ${ }^{47}$ Baghdad and Tehran are about 450 miles apart, but Baghdad is about 100 miles from the border while Tehran is about 350 miles from the same boundary.

Based on just the distance and air defense assets between the border and the capitals, the Iranians would have an easier time reaching their targets. One final comparison of the two air forces can be made in the area of operational readiness. The Iranian Air Force was estimated to be about fifty percent operational while the Iraqis, knowing that they were about to attack were at maximum operational readiness. ${ }^{48}$ There are three strategic areas in each of the two countries. In Iran, these are Tehran, the oil-rich coastal plain of Khuzistan, and the Bandar Abbas area which guards the Straits of Hormuz. In Iraq the areas of major importance are Baghdad a strategic, political and economic target; the rich oil field of Kiruk, in the north; and the Basra area on the Shatt-alArab. ${ }^{49}$

As the offensive force, Iraq had little chance of seriously affecting either Tehran or the Bandar Abbas areas, because of the distances from Iraq. Rather, the Iraqis chose to concentrate on securing the Iranian oil fields in Khuzistan and Abadan Island. There were several very lucrative targets in Khuzistan. Khorramshahr, Iran's main port, and Abadan, the world's largest oil refinery with a 1978-estimated capacity of 600,000 barrels per day, were both located In the province. Futhermore, Dezful and Ahvaz are key points on the Iranian pipeline and both were important military bases. ${ }^{50}$

In the south, any chances of securing the Iranian oil fields, protecting the Shatt-al-Arab, and creating the Arabestan province rested on seizing Dezful, Ahvaz, Khorramshahr and the Island of Abadan. This was where the main attack would occur. The northern and central fronts were to be economy-of-force defensive operations. Five divisions were committed to the northern highlands; two divisions were sent against the center to protect Baghdad; and five divisions (three armored and two mechanized) were poised opposite the Khuzistan Province. ${ }^{51}$

Iran's remaining four understrength divisions were deployed as follows: one infantry division near Urumiyeh, in the far north; one infantry division at Sanadaj to keep and eye on the Iranian Kurds; an armored division at Kermanshah and a brigade at Qasr-e-Shirin; and an armored division at Ahvaz which protected the air base at Dezful. ${ }^{52}$ Khorramshahr and Abadan had been isolated but not secured because of the unexpectedly tenacious Iranian defense.

The Iraqis had diluted their forces in the south by attacking several objectives simultaneously rather than capturing Ahvaz or neutralizing the airbase at Dezful. The Iraqis had been able to maintain an advantage of about 5 or $6: 1$ in the south but did not achieve the tactical or strategic 
results that were necessary to throw Iran into turmoil. The second phase of the war began with Bani Sadr's unsuccessful attempt at retaking Susangerd in January 1981. The fact that the attack was unsuccessful can be misleading because it was the last major defeat for the Iranians thus far..$^{53}$

In addition to the armor regiments (about 300 Chieftains and $\mathrm{M}-60^{\prime} \mathrm{s}$ ) that were committed by the Iranians, a parachute regiment was also used as a conventional ground force. However, the Iraqis foresaw the attack and prepared their defensive positions. Accordingly, as the Iranians attacked, the Iraqis pulled back a few kilometers toward the Kharek river and set up a three-sided ambush. ${ }^{54}$ The Iranians, thinking that the Iraq is retreating, rushed in with their armor forces. Over the course of the next four days the two divisions fought each other by employing their helicopter gunships and tanks. The Iranians were caught in untrafficable terrain and had to leave about 100 to 150 tanks on the battlefield; the Iraqis then pursued the fleeing Iranians about sixty more kilometers into Iranian territory before halting. ${ }^{55}$

The Iraq has lost about 100 tanks themselves as well as other war machines. Moreover, the captured Iranian tanks were of little value to the Iraqis because they had no training on the American and British equipment. The Jordanians did have Western equipment, however and became the real winners of this battle because they received the captured Iranian tanks without having participated in the fighting. ${ }^{56}$

Although the Iraqis had had a year to prepare their positions they found themselves being pushed back by the Iranians.through December 2 , 1981. American analysts doubt the veracity of either report. ${ }^{57}$ The second point is that the Iraqis were unable to hold their positions. The December $9^{\text {th }}, 1981$, New York Times reported that after a long-term Iranian offensive, President Hussein told Iraqi troops "it is very important that you not lose any more positions." ${ }^{58}$ At about 0300 on March 22, the Iranians surprised the Iraqis by attacking at an unexpected time, from an unexpected direction and with an extra division. ${ }^{59}$ The Iranians had been successful to outflank the Iraqi positions and to attack the weak points. Iraqi losses, as at Abadan in September 1981, were tremendous. Western observers estimate that over 600 tanks and armored vehicles, 10,000 casualties and 15,000 POW's were lost. Iranian casualties were placed at about 10,000 including 3,000 to 4,000 killed. $^{60}$

In April 1982 the Syrians performed a series of diplomatic, economic and military maneuvers that weakened the Iraqi fighting posture while strengthening that of the Iranians. The Syrians had chosen to back the Iranians for several reasons. First, the Syrian government is drawn from the Alawite faction which is Shiite in its orientation and, therefore, is inclined towards Iran and away from Iraq. ${ }^{61}$ More importantly, President 
Assad of Syria had long spoken of a "Greater Syria." Were Iraq to be victorious, it would strengthen the Riyadh-Amman-Baghdad axis that President Hussein was attempting to maintain. This axis would effectively reduce Syria's ability to influence the Arab world and undermine Syria's claim to be the true leader of the Ba' ath movement. ${ }^{62}$

To ensure that the Syrians attain the position of prominence in the Arab World, President Assad had taken strong measures to weaken his rival claimant in Iraq. In addition to providing moral support to Iran, the Syrians cut-off the Iraqi oil pipeline that runs through Syria. It is also suggested that the Syrians provided fuel for Iranian fighters after a mission over Iraq. The Iranian aircraft flew over Iraq and disappeared from Iraqi radar over Syrian territory. Sometime later, the aircraft reappeared over Syria and made the return flight to Iran. ${ }^{63}$

The Iranian attack was a well-coordinated effort making effective use of the various combat arms. Infantry night attacks were followed by armor thrusts and fighter aircraft and helicopter support. Initial success was good but stiff resistance was met in the northern area and in front of Khorramshahr, where the Iraqis adopted a more flexible defense. Advice from French and Jordanian advisors apparently assisted the Iraqi regulars in performing better but the Iraqi volunteer units did not fare as well. ${ }^{64}$

The casualties sustained by both sides were again high, with the Iraqis losing about 7,500 and the Iranians losing about $2,500 .{ }^{65}$ Of the three axes, the two more successful ones were at Abadan and around Khorramshahr while the effort in the north was less than fruitful. ${ }^{66}$ Iraq ended November 1982 with again seeking unity among the Arabs and making more peace proposals. Iran could not be appeased even by Iraqi declarations of unilateral truce. Iran's preconditions for negotiations were impossible to meet.

These preconditions were: the fall of the government of Saddam Hussein; Iraq's admission of its responsibility for starting the war; the withdrawal of all Iraqi troops from and the return of all Iranian territory; the payment of from $\$ 50$ to $\$ 150$ billion in war reparations; and the return to Iraq of the Persian Shiites who had been expelled by President Hussein in $1980 .{ }^{67}$ The war is believed to be costing Iraq about $\$ 1$ billion a month. To meet these costs, Baghdad has been subsidized by Kuwait and Saudi Arabia to but weapons. ${ }^{68}$ With the purchase of French Super Etendard fighter-bombers the Iraqis may be able to interdict the Iranian Sea Lines of Communication. The Super Etendard, with a speed of 730 m.p.h., an unrefueled range of 530 miles and equipped with the Exocet missile, was felt to be a serious threat by the Iranians. ${ }^{69}$ 


\section{Ayatollah Khomeini and the Iran-Iraq War}

The Ayatollah Khomeini was exiled to Iraq for anti-Shah activities during a period of rapprochement between the two countries. To placate the Shah, Saddam Husein placed Ayatollah Khomeini under house arrest in 1975. Three years later, Saddam Hussein expelled the Ayatollah, who fled to France. ${ }^{70}$ In 1977, one of the Ayatollah's sons was mysteriously murdered in Iraq. One of Iraq's leading Shia clerics was executed to quell the Islamic fundamentalist movement that was brewing. The execution was personally ordered by Saddam Hussein. ${ }^{71}$ When Khomeini came to power in 1979, he immediately declared that Iraq "belongs in the dustbin of history". ${ }^{72}$

A reporter Asked who his enemies are, the Ayatollah replied, "First the Shah, then the American Satan, then Saddam Hussein and his infidel Baath Party." ${ }^{73}$ The feeling between the leaders of the two warring nations was, and is, quite bitter. During the Ayatollah Khomeini's exile period, The Shah of Iran had counted on the military, with his handpicked loyal generals, to maintain him in power. But the generals were unable to cope with the situation because the Shah was not around to issue the customary detailed, written orders to which they were accustomed. ${ }^{74}$

In the wake of the Iranian revolution, decimation of the Iranian army seemed natural. The Shah's army was considered counterrevolutionary and purges could be expected. By the fall of 1980, 10,000 military personnel had been dismissed, imprisoned, or executed..$^{75}$ In 1979, the Revolutionary Council decreed that the entire Iranian nation would become soldiers of the revolution. During the hostage crisis, Khomeini emphasized this theme and called for the creation of an "Army of Twenty Million". ${ }^{76}$

The lower ranks of the army, mostly conscripts, turned to the religious revolution when it became apparent that they had no leadership. Besides, the revolutionaries were from the same class of society as the soldiers, the lower and middle classes, and they had no strong bonds with upper class leaders. ${ }^{77}$ Western-trained Iranian army officers were eliminated during the revolution conflicts and Shiite clergy were installed at each base and at each level of command. One method of countering the armed forces potential threat was to create a separate paramilitary force (the 'elite' guard) loyal to the regime.

A loose alignment of these hawkish leaders argued that Iran should parlay its successful military operations into a counter-invasion of Iraq. ${ }^{78}$ The result, Iran's counter-invasion of Iraq, ushered in a new stage in the war. Through the next six years, Iran's offensives were met with occasional but limited success. Despite some victories inside Iraq, the realities of occupying and holding territory against the galvanized and 
better equipped Iraqi defenses proved too formidable for Iran's armed forces to overcome. Iraqi forces (backed in part by the US, France, and Arab Gulf states), now in the position of defending their cities and territory, effectively prevented Iran from realizing its stated goals of igniting an Islamic revolution in Iraq and overthrowing the Baathist regime. $^{79}$

The self-assurance that drove Iran's war policy in Iraq also inspired extraterritorial ambitions. Iran's leaders framed the Iraq war as one front in the Islamic world's larger struggle against imperialist and Zionist influence. The Israeli invasion of Lebanon on 6 June 1982 and the on going Soviet conflict in Afghanistan-supported this line of thinking. ${ }^{80}$ Although it had long been part of Ayatollah Khomeini rhetoric, support for the Palestinian cause became a central theme in the wartime mission promoted by the Revolutionary Guards. Before Iran's counter-invasion in 1982, the Revolutionary Guards called for the establishment of a multinational Muslim force to liberate the holy city. The idea for this force, called the "Jerusalem Army" or in Persian [sepah-e qods], arose from a meeting of foreign Islamic organizations in Iran in 1981. ${ }^{81}$ Regarding this force, the IRGC announced:

"Referencing Ayatollah Montazeri's calls for exporting the Islami revolution, the IRGC claimed that the liberation of Jerusalem was its "task before all tasks," but argued that Saddam Hosein's invasion had blocked its "assault" on the holy city." 82

The IRGC further suggested that the "greater victory" of delivering Jerusalem from Israeli occupation could only be achieved after the "lesser victory" of defeating Saddam Hosein. Therefore, Iraq became seen as both the literal and figurative gateway to Jerusalem and the first step towards the ultimate emancipation of Muslim societies. The IRGC employed the idea of liberating Jerusalem in an effort to inspire (and perhaps appease) its rank-and-file, who embraced interventionist ambitions more wholeheartedly than the organization's conservative top command..$^{83}$

In this manner, the underlying conservatism of Mohsen Rezai and Iran's Supreme Defense Council is evident in the priority given to the Iraq war in the "greater" quest for Jerusalem. For, only after the war with Iraq is won can Iran begin its "assault" on Israel. The longer the war went on, however, the more distant the prospect of liberating Jerusalem grew and the more hollow the cheering of such slogans became ${ }^{84}$ Even though a small presence of IRGC officials remains in Lebanon to this day, many of its troops began to pullout in 1985 as resistance to Iran's extraterritorial efforts in general, and in Lebanon in 
particular, became a charged subject in Iranian politics. ${ }^{85}$ This shift in policy was a consequence of the growing international pressure against Iran's involvement in Lebanon (i.e., terrorism and hostage-taking) and simmering political divergence within Iran's leadership.

By 1984, President Khamenei and parliament speaker Rafsanjani publically acknowledged that there was an internal ideological dispute between conservatives and left-leaning radicals within the Ayatollah Khomeini bloc. Although this split had been apparent years before (e.g., as evinced by Mohsen Rezai's resignation from MIR ${ }^{86}$ in 1982), the intensification of the Iraq war and its impact on Iranian society brought factionalism to the political force. Each faction included prominent members of the regime, including Khamenei and Rafsanjani for the conservatives (who Ayatollah Khomeini tended to support on foreign policy), and Mohtashami, Behzad Nabavi (the leader of MIR), MirHosayn Musavi (the Prime Minister), and Ayatollah Montazeri for the more revolutionary-minded left. ${ }^{87}$

This ideological conflict and related political infighting permeated major political parties and led the dissolution of MIR (1986) and the $\operatorname{IRP}^{88}$ (1987) thereby undoing the alliances that had laid the foundation for Ayatollah khomeinist dominance in post-revolutionary Iran. While disagreements over social and economic policy were important contributors to the factionalism within the Ayatollah khomeinist movement, the area of foreign policy, and more specifically the issue of foreign involvement, proved central to the political divide. ${ }^{89}$

More conservative elements led by Rafsanjani regarded foreign involvement to be a waste of resources, harmful to Iran's international standing, and a distraction from the conflict with Iraq..$^{90}$ On the latter issue, Rafsanjani was supported by Ayatollah Khomeini and the leading architects of the Iraq war, including IRGC commander Mohsen Rezai, who wanted to concentrate Iran's military resources on victory in Iraq. To bolster Iran's lagging war effort, Rafsanjani opened up unofficial contacts with the US and Israel to explore arms purchases. ${ }^{91}$

Although Iran had been secretly purchasing American arms through Israel with Ayatollah khomeini's assent since the beginning of the war, a need to replenish its stockpiles pushed Rafsanjani to seek a direct covert deal with the US. ${ }^{92}$ Through intermediaries in his cabinet and abroad, Rafsanjani sought shipments of US anti-tank TOW missiles in return for a cessation of Iran-sponsored terrorism in Lebanon, a promise to release four American hostages held captive by Hizbullah, and a suggestion of an eventual rapprochement with the US. ${ }^{93}$

To help seal the deal with the Americans, Rafsanjani invited an US and Israeli delegation to Tehran to discuss the plan. While the secret meeting failed to produce an agreement, a commitment 
was made between the US delegation (headed by Robert McFarlane, former National Security Advisor to Ronald Regan) and Rafsanjani's representatives to keep back channels open for future discussions. ${ }^{94}$ The radical-left faction associated with Ayatollah Montazeri, Mehdi Hashemi, and Mohtashami, largely opposed Rafsanjani's overtures. Montazeri, for instance, personally criticized Rafsanjani for the secret meeting in Tehran. ${ }^{95}$ For this faction, which had broad support within IRGC ranks, it was Iran's moral and political responsibility to assist Muslim resistance movements and propagate the values of the Islamic revolution across the region. ${ }^{96}$

Further, as combating the influence of imperialism and liberating Jerusalem remained at the forefront of their idealistic agenda, the internationalist faction rejected any warming of relations between the US and Israel. Lebanon, for this group, was seen as a successful example of what exporting the revolution could achieve and as a crucial front in the war against imperialism and zionism that required continued support. ${ }^{97}$

Therefore, any negotiations with the US, particularly any involving a deal promising a scaling-back of Iran's Lebanese presence, were anathema to the radicals and would provoke a reaction. The conservatives, however, proved the more formidable coalition. Simultaneous with seeking a US arms deal, Rafsanjani sought to weaken his rival Montazeri by undermining the influence of the latter's leftist base. With the crucial support of Ayatollah khomeini, Rafsanjani was able to remove the Office of Liberation Movements from the IRGC and mix it with the Foreign Ministry thereby bringing the office's operations under the direct control of the government and curtailing its semiautonomy. ${ }^{98}$

While this was a blow to radical-interventionists, Mehdi Hashemi (Montazeri's relative through marriage) and his supporters were able to continue their foreign operations with the financial and political support of Montazeri. However, after Hashemi was arrested by Saudi security agents for attempting to smuggle explosives into that country for a purported attack during the annual Hajj in Mecca, the interventionist faction began to fall apart. ${ }^{99}$ Hashemi returned to Iran where he was detained and an investigation into his activities commenced. While Montazeri vigorously protested the arrest in letters to Ayatollah khomeini, 100

Some of Hashemi's associates leaked information to a Lebanese newspaper exposing the covert negotiations and attempted arms purchases between Rafsanjani, the US, and Israel, setting off what came to be known as the Iran-Contra affair. ${ }^{101}$ The attempt to undermine Rafsanjani backfired. Despite political pressure from the leftist factions, Ayatollah Khomeini intervened on Rafsanjani's behalf and blocked 
attempts for an official investigation into the matter. With Ayatollah Khomeini's backing, Rafsanjani led a crackdown on radical activists resulting in the mass arrests of Hashemi and Montazeri's supporters, including "hundreds" from the ranks of the Revolutionary Guards. ${ }^{102}$

By 1987, the radical-left faction, which had become tainted by its association with Hashemi (who was forced to publically confess to crimes against the Islamic revolution and subsequently executed that year), had lost much of its influence within both the IRGC and the government. In 1988, Rafsanjani further constrained this bloc by removing Mohtashami from the Lebanon desk at the Foreign Ministry and replacing him with the former's brother. ${ }^{103}$

With this act, Rafsanjani sent a clear signal that Iran's foreign policy would no longer follow an interventionist path and would instead conform to the policies of the conservative-led administration. In August 1988, Iran and Iraq agreed to a ceasefire, effectively ending the eightyear war. The end of the war also marked the political decline of the radical left. This faction lost its main patron when Ayatollah Montazeri resigned from his position as Ayatollah khomeini's successor in March 1989 after the former's sharp criticism of the state's violent suppression of political dissidents caused a fallout between the two clerics. ${ }^{104}$

Although the Islamic Republic and the IRGC would continue limited foreign involvement after the war, the style of interventionism promoted by Montazeri, Mohtashami, and Hashemi-i.e., the militaristic exportation of the revolution abroad-would not return to the political mainstream. Indeed, in the months leading up to his resignation, Montazeri himself had begun to move away from this position. His attitude, which he began to articulate around this time, encapsulates the Islamic Republic's general postwar line on exporting the revolution:

"The question of exporting revolution.is not a matter of armed intervention.
The aim was, rather, by building our country on the basis of Islam's
command and making the customs of the Prophet and the immaculate Imams
our model; by implementing the aims, ideas and values which have been
stressed and cherished by Islam, to have our country and our revolution
become a model for other deprived countries and countries oppressed by
and subject to cruelty from the superpowers. They would choose our way
to liberate themselves from the yoke of imperialis."

The Islamic Revolutionary Guards were fanatically loyal to the Ayatollah and his revolution. Though they lacked military training they assumed the duties of the regular armed forces. ${ }^{106}$ In the January 1981 attack, the Iranians went against prepared positions through open wetlands that restricted their movement and limited their cover. In addition, over 200 
sorties a day were flown by the improving Iraqi Air Force, which could take credit for some of the nearly 6,000 Iranians who were killed. ${ }^{107}$

When Seyed Ali Khameneyi [current Islamic revolution leader of Iran] took over the Iranian Presidency in August 1981, the change in leadership did not end the war there and then. On the contrary, the Iranians were even more determined to fight in view of Ayatollah Khomeini's perceived spiritual leadership. The specific character of Ayatollah Khomeini's constituted a powerful moral asset in repelling the Iraqi attack by young Iranian soldiers. ${ }^{108}$ Recruiting young Iranian soldiers was because of Iran has developed simple plans for a different reason during the war. Simply, the Iranians to longer possess the military resources that allow them to develop and execute complex plans.

By early 1981, the Iranians had very little armor, air or artillery. However, they did have an abundance of men who were willing to die for their Revolution. Realizing this, the Iranian military developed plans that were by Western standards simple. Fifty to one hundred thousand troops were involved in this most bitter struggle which raged until October $10^{\text {th }} 1988$. Without the benefit of air or armor, the Iranians resorted to human wave assaults against the well-prepared Iraqi positions. Losses in one engagement alone were over 4,000 Iranians and 300 Iraqis killed. ${ }^{109}$

There were the battles at Iraq's Fao Peninsula. The surprise attack on Fao by Iranian troops in February 1986 and the successful repulsion of Iraqi counter-attacks marked one of the major turning points in the war. Fao raised serious doubts in the region, as well as in Moscow and Washington, about Iraq's ability to use its qualitative military superiority effectively. Besides having a population three times more than Iraq, the less well-equipped Iranian forces also appeared to be much more highly motivated than those of Iraq. The breakthrough at Fao only seemed to confirm that an Iranian victory was possible and was a matter of time. However, Iran's subsequent attacks did not make much headway after Fao, and in April 1988, the Iranian forces were in turn driven out of Fao. Until then, Iraq had always deliberately sought to avoid high casualty rates for fear of undermining the already tepid popular support for the war. ${ }^{110}$

In mid-1987, there were several indications that the Iranian leaders were at least reassessing their approach to the war. First, Iran's willingness to tolerate the superpowers' decision to escort Kuwaiti shipping suggested that Iran somehow welcomed the diversion in a sideshow of the war rather than concentrate on the serious prosecution of the war on land. Second, Iran's unwillingness to reject the Security 
Council Resolution of July 1987 outright but sought modifications was also indicative of a change in attitude. Third, Iran's still ambiguous war aims had nonetheless been modified over previous months; the demand for the removal of Saddam Hussein still stood, but the insistence on the removal of the Ba'th regime, reparations, and the installation of an Islamic republic had disappeared. Finally, the stream of volunteers for the front had dwindled and Iran's leaders, notably Rafsanjani, had begun to talk publicly in mid-1987 of terminating the war unless it began to interfere with the political administration of its society. ${ }^{111}$

\section{Conclusion}

Ayatollah Khomeini urged the Iranians to viewed their participation in the conflict as a defense of Islam; thus, compromise with the Iraqi "usurpers" was out of the question. Viewing the conflict as the "Imposed War," Tehran considered the conflict from a vastly different perspective than Saddam Hussein. For Iran, the conflict was less a war over territory andcontrol of the Shatt al Arab waterway than a standoff between absolute good (Iran) and absolute evil (Iraq). Ayatollah Khomeini defined the war as a battle between good and evil as he said to his commanders "You are fighting to protect Islam and he (Saddam Hosein) is fighting to destroy Islam".

However, in the last years of the war, there were indicators that Iran's soldiers were unwilling and unable to continue the fight because the war aims were not achieved and had lost a string of military battles in Fao, Shalamcheh, Mehran and Majnoon in southwest of Iran. Coupled with a sense of isolation and confrontation not only with Iraq but also with the whole world, hastened Iran's decision to end the war. At the end of the war, on July 3rd 1988, a fortnight before accepting a ceasefire in the Iran-Iraq War, the powerful speaker of parliament and military Commander-in-Chief (since July 1980), Ayatollah Ali Akbar Hashemi Rafsanjani said that Iran's new priority was to break out of international isolation.

He had long believed that the major casualty of this war had been the creditability of the Islamic Republic among its own rank. He believed that the longer the war prolonged, the more Iran could no longer effectively call upon its populace for sacrifices and martyrdom. It was for this reason that Rafsanjani had indulged in pre-emptive self-criticism of past policies long before the final ceasefire call in 1988. Therefore, Rafsanjani had taken a risk in persuading the Ayatollah Khomeini to accept the ceasefire. In July 1988, Ayatollah Khomeini, announced the acceptance of ceasefire. 


\section{Notes}

1 Khorramshahr is the closest Iranian Port near to Iraq border playing an important role to economy of Iran as well.

2 Ruhollah.Khomeini, Tawzih al-Masa'il, Tehran: Entesharat-e Iran Press, 1999, pp. 454-455.

3 Imam Khomeini, Defense Readiness, Grade 8 [Persian School Books], Tehran: Ministry of Education, 2004, p. 1;Imam Khomeini, Defense Readiness 1, High School Grades [Teacher's Guide], (Tehran: Ministry of Education, 2002), front cover; Imam Khomeini, Defense Readiness 2, High School Grades [Teacher's Guide], (Tehran: Ministry of Education, 2003), front cover.

4 Anthony H. Cordesman, Lessons of the Iran-Iraq War: The First Round, Armed Forces Journal International, 1982, p. 29.

5 Dilip Hiro, The Longest War, The Iran-Iraq Military Conflict, New York: Routledge, 1991, p. 25.

6 See discussion, for example, in Samir al-Khalil, Republic of Fear: The Politics of Modern Iraq, California: University of California Press, 1989, p. 261.

7 Statistics on human and village loses extracted from Amir Taheri, The Cauldron: The Middle East behind the Headlines, London: Hutchinson, 1988, pp. 198-199. On refugees, see Martha Wenger and Dick Anderson, "The Gulf War", MERIP Middle East Report, Vol. 17, No. 5, September-October 1987, p. 25.

8 Farhang Rajee, Iranian Perspectives on the Iran-Iraq War, Gainesville Florida: University Press of Florida, 1997, p. 14.

9 Bijan Mossavar-Rahmani, Economic Implications for Iran and Iraq in The Iran-Iraq War: New Weapons, Old Conflicts, edited by Shirin Tahir-Kheli and Shaheen Ayubi, New York: Praeger Press, 1983, pp. 138-140. Farhang Rajee, Iranian Perspectives, p. 3.

11 Efraim Karsh, The Iran-Iraq War: Impact and Implications, London: MacMillan Press, 1989, pp. 19-22.

12 Dilip Hiro, The Longest War, pp. 264-265.

$13 \quad$ Ibid., p. 264.

14 Anthony H. Cordesman, Lessons of the Iran-Iraq War, p. 32.

15 Daniel Pipes, A Border Adrift: Origins of the Conflict in The Iran-Iraq War: New Weapons, Old Conflicts, edited by Shirin Tahir-Kheli and Shaheen Ayubi, New York: Praeger Press, 1984, p. 121.

16 Anoushiravan Ehteshami and Gerd Nonneman, War and Peace in the Gulf and Shahram Chubin and Charles Tripp, Iran and Iraq at War, London: I.B. Tauris, 1988 , pp. 40-52.

17 For two accounts of the first half of the war, see Dilip Hiro, Chronicle of the Gulf War, (Merrip Reports: July/September), pp. 3-14; Ghassan Salameh, "Checkmate in the Gulf War", MERIP Reports, Vol. 14, No. 6/7 (July - September, 1984), p. 82. See also Efraim Karsh, "The Iran- Iraq War: A Military Analysis", in Adelphi Papers, No. 220, London: International Institute for Strategic Studies, 1987, p. 119.

18 Abbass Ali Akbari, Nabarde Jango Zendegi Nojavanan Dar Jebhe [Struggle for Life and Death] Tehran: Sacred Defense Publishing, 2003, p. 34. 
Majid Khadduri, The GulfWar, New York: Oxford University Press, 1997, p. 28.

Efraim Karsh, The Iran-lraq War, p. 10.

Ibid., p. 11.

Anthony H. Cordesman, Lessons of the Iran-Iraq War, p. 74.

John W. Limbert, Iran: At War with History, Colorado: Westview Press, 1987, pp. 135-142.

Kamran Scott Aghaie, The Martyrs of Karbala: Shi'i Symbols and Rituals in Modern Iran, Seattle and London: University of Washington Press, 2004, p. 106; Stephen R. Grummon, The Iran-Iraq War, pp. 1-3.

Richard A. Gabriel, Fighting Armies, Antagonists in the Middle East: A Combat Assessment, Westport Connecticut: Greenwood Press, 1983, p. 86.

William O. Staudenmaier, A Strategic Analysis of the Gulf War, Carlisle Barracks, Pennsylvania, U.S: Army War College, 1982, p. 2.

Mansour Farhang, "The Iran-Iraq War: The Feud, the Tragedy, the Spoils", World Policy Journal, Fall 1985, pp. 663-664. See also discussion in Samir al-Khalil, Republic of Fear, pp. 262-264.

Daniel Pipes, "A Border Adrift", p. 21. Pipes is particularly critical of those accounts of the war which over-emphasize the cultural dimensions of the war.

See introductory discussion in Talal Asad and Roger Owen, Sociology of Developing Societies: The Middle East, New York: Monthly Review Press, 1983, pp. 7-8.

American Foreign Policy Institute, The Impact of the Iranian Events upon Persian Gulf and U.S. Security, Washington D.C.: Foreign Policy Institute, 1979, pp. 39-64.

Stephen R. Grummon, The Iran-Iraq War, p. 2.

Thomas M. Daly, "The Not Too Forgotten War," Naval Institute Proceedings, June 1984, p. 39.

Ibid., p. 265.

Hamid Algar, "Shi ism and Iran in the Eighteenth Century", in Studies in Eighteenth Century Islamic History, Southern Illinois University Press, 1977, pp. 92-119. "Shi'ites: A Feared Minority", Time, July 26, 1982, p. 24. Mansour Farhang, The Iran-Iraq War, pp. 663-664; Samir al-Khalil, Republic of Fear, pp. 262-264.

6 Robert Bernard O'Donnell, A New Arab Alliance System: Causes of the Iran-Iraq War and the Reaction of Various Arab States, M.A. Thesis, Naval Post Graduate School, California, 1981, p. 34.

William O. Staudenmaier, A Strategic Analysis, pp. 8-9. See also Annabelle Sreberny-Mohammadi and Ali Mohammadi, Small Media, Big Revolution: Communication, Culture, and the Iranian Revolution, Minneapolis: University of Minnesota Press, 1994, pp. 60-62. Glen Balfour-Paul, The Prospects for Peace in the Iran-Iraq War, edited by M.S. El- Azhary Croom Helm, 1984, pp. 69-99.

39 Stephen R. Grummon, The Iran-Iraq War, p. 38. Fred Halliday, "Iran's New Grand Strategy", MERIP Middle East Report, Vol. 17, No. 1, January-February 1987, p. 7. 
Anthony H. Cordesman and Abraham R. Wagner, The Lessons of Modern War: The Iran-Iraq War, Boulder CO: Westview Press, 1990, p. 484. Anoushiravan Ehteshami and Gerd Nonneman, War and Peace, p. 92. Anthony H. Cordesman and Abraham R. Wagner, The Lessons of Modern War, pp. 485-489.

Javid Ali, "Chemical Weapons and the Iran-Iraq War: A Case Study in Noncompliance", Nonproliferation Review, Spring 2001, pp. 47-48.

Shahram Chubin, Iran's National Security Policy: Capabilities, Intentions and Impact, Washington: Carnegie Endowment for International Peace Press, 1994, p. 21

William Scott Malone, David Halevy and Sam Hemingway, "The Guns of Saddam", Washington Post, 10 February 1991, p. 6.

Anthony H. Cordesman and Abraham R. Wagner, The Lessons of Modern War, pp. 222, 262.

William O. Staudenmaier, A Strategic Analysis, p. 6.

See Annabelle Sreberny-Mohammadi and Ali Mohammadi, Small Media, p. 53.; William O. Staudenmaier, A Strategic Analysis, pp. 8-9.

Alvin Cottrell, The Persian Gulf States, Baltimore: The Johns Hopkins University Press, 1980, p. 631.

Anthony H. Cordesman, Lessons of the Iran-Iraq War, p. 44.

William O. Staudenmaier, A Strategic Analysis, p. 10.

Ibid., p. 11.

William O. Staudenmaier, A Strategic Analysis, New York: Praeger Press, 1983, p. 16.

Anthony H. Cordesman, Lessons of the Iran-Iraq War, pp. 60-80.

Gary C. Demack, "Perception and Misperception in the Persian Gulf: The Iran-Iraq War", Parameters, June 1983, p. 26.

Ibid., p. 27.

Anthony H. Cordesman, Lessons of the Iran-Iraq War, p. 73.

Ibid., pp. 73-74.

Iran, Iraq Report Victories along the Southern Front", Washington Post, 23 March 1982, p. 5.

Davood Amirian, Shemr va Saddam va Hamrahanash [Shemr, Sadam and his Companions], Tehran: Shahed Publication, 2008, pp. 13-14.

Stephen Grummon, The Iran-Iraq War, p. 46.

William O. Staudenmaier, A Strategic Analysis, p. 21.

Anthony H. Cordesman, Lessons of the Iran-Iraq War, p. 74.

Ibid., p. 75.

"Iran Launches New Offensive against Iraqis", Washington Post, 1 May 1982, p. 9.

Christine Moss Helms, The Iraqi Dilemma: Political Objectives versus Military

Strategy, Washington.: The Brooking Institution, 1983, p. 84.

James Kelly, "Battling for the Advantage", Time, 24 October 1983, p. 35.

See also Christine Moss Helms, The Iraqi Dilemma, p. 82.

James Kelly, "Battling for the Advantage", Time, 24 October 1983, p. 34.

"Personal Power, Personal Hate", Time, 26 July 1982, p. 25. 
Evans. D, Iran-Iraq: Bloody Tomorrows, US: Naval Proceedings, 1985, p. 33. See also Abdulaziz Sachedina, The Rule of the Religious Jurist in Iran: In Iran at the Crossroads, New York: Palgrave, 2001, pp. 70-73.

Ibid., p. 93. See also Barnett Rubin, Armed Forces in the Middle East Politics and Strategy, London: Routledge, 2002, pp. 10-14.

"Personal Power, Personal Hate", Time, 26 July 1982, p. 25.

William F. Hickman, Ravaged and Reborn: The Iranian Army, Washington, The Brookings Institution, 1982, p. 6.

Ibid., pp. 6-16.

Ibid., p. 10.

Ibid., p. 14.

Dilip Hiro, The Longest War, pp. 86-87.

Hasan Jalali, Be Yade Farmandehan va Sardarane Shahid [For the Memory of Martyred Commanders], Tehran: Martyrs Foundation of Islamic Revolution, 1998, p. 30.

Mehdi Saidi, Sazman-e Mojahedin-e Enqelab-e Eslami: az tasis ta enhelal [Mojahedin of Islamic Revolution from founding to dissolving], Tehran: Markaz-e Esnad-e Enqelab-e Eslami, 2007, p. 51.

This commitment appears in the IRGC's first official charter. See Sepahe Pasdarane Enghelabe Eslami, Payam-e Enqelab, No. 47, 12 December 1981, p. 2.

Sepahe Pasdarane Enghelabe Eslami, Payam-e Enqelab, No. 47, 12 December 1981, p. 12.

Ibid., p. 13.

Shahram Chubin and Charles Tripp, Iran and Iraq at War, London: Workman, 1988, pp. 93-94.

"Leaflets and songs show Iranian link to Beirut's Party of God", Christian Science Monitor, 29 April 1985, p. 11. This process continued through the early 1990s, by which time the vast majority of IRGC troops had been removed from Lebanon. See Hamzeh Nizar, In the Path of Hizballah, New York: Syracuse University Press, 2004, pp. 69-71.

MIR, Mojahedin of Islamic Revolution.

Mehdi Moslem, Factional Politics, New York: Syracuse University Press, 2004, pp. 47-70.

IRP, Islamic Revolution Party.

For a detailed discussion of the form and content of the debates that fostered the factionalism of this period, see Mehdi Moslem, Factional Politics, pp. 47-81.

David Menashri, Iran: A Decade of War and Revolution, New York: Holmes \& Meier, 1990, pp. 374-378.

Ibid., p. 378.

On Iran's covert arms purchases from the US and Israel, See Trita Parsi, Treacherous Alliance: The Secret Dealings of Israel, Iran and the U.S., New Haven: Yale University Press, 2007, p. 96; Ray Takeyh, Hidden Iran: Paradox and Power in the Islamic Republic, New York: Times Books Press, 2006, pp. 103-10; Gary Sick, October Surprise: America's Hostages in Iran and the Election of Ronald Reagan, New York: Times Books, 1991, p. 13. 
Hosayn-Ali Montazeri. Khaterat-e Ayatollah [The Memorials of Ayatollah Montazeri], Los Angeles: Ketab Corp, 2001, p. 212.

Trita Parsi, Treacherous Alliance, New Heaven: Yale University Press, 2007, pp. 113-123.

Hosayn-Ali Montazeri, Khaterat-e Ayatollah, p. 339.

Kenneth Katzman, Warriors of Islam Iran's Revolutionary Guard, Boulder: Westview Press, 1993, pp. 150-152.

David Menashri, Iran: A Decade of War, pp. 379-82.

Hosayn-Ali Montazeri, Khaterat-e Ayatollah [The Memorials of Ayatollah Montazeri], p. 156.

David Menashri, Iran: A Decade of War, pp. 379-380.

Montazeri discusses these events in his memoirs. See Hosayn-Ali Montazeri, Khaterat-e Ayatollah, pp. 335-346. Also, for exchanges between Ayatollah Khomeini and Montazeri regarding the arrest of Mehdi Hashemi, see Baqer Moin, Life of the Ayatollah Khomeini, New York: I. B. Tauris, 2009, pp. 277-293.

Trita Parsi, Treacherous Alliance, pp. 123-126; David Menashri, Iran: A Decade of War, pp. 379-380.

"Hundreds of Montazeri supporters arrested," Tehran Newspaper, 14 November 1986, p. 3.

Kenneth Katzman, Warriors of Islam, pp. 147-160.

Montazeri had been elected in 1985 by the Assembly of Experts to be Ayatollah khomeini's successor. His vocal criticism of the violent political suppression under the Ayatollah khomeini regime led to a fallout between the two senior clerics. For exchanges between the two, see Baqer Moin, Ayatollah Khomeini, pp. 262-98.

Ervand Abrahamian, The Iranian Mojahedin, New Haven: Yale University Press, 1992, pp. 36-41.

Ibid., p. 41.

Joseph Panossian, "Iran Starts Offensive, Claims Major Gains”, Washington Post, February 8. 1983, p. 9

Hanns Maull, The GulfWar: Regional and International Dimensions, London: Pinter Press, 1989, p. 67.

Anthony Cordesman, The Iran-Iraq War: Attrition Now, Chaos Later, Washington: Armed Forces Journal International, 1983, p. 38.

Efraim Karsh, The Iran-Iraq War: Impact and Implications, London: MacMillan Press, 1989, p. 16.

Ibid., p. 20. 